a 5-ft. length, and their energy will fail to do so until they become $20 \mathrm{ft}$. long. Presumably waves do form near the weather shore when it' starts to blow, but it looks as if they must be soon dispersed by breaking. The solution may be that those which form to leeward, and so in their early life are independent of speed over the ground, attain the lengths necessary for survival before they are swept back to the weather shore. In that case there should be waves of appreciable length where there is almost inappreciable fetch, after the wind has been blowing long enough for the conditions to be stabilized. It would be interesting to know what actually does happen.

But assuming that a stable regime has been attained, it is possible to roughly estimate the change in the demand for wind energy, and so the surplus available for increasing the sea, that a weather-going stream entails. Wave power over the ground is $E(G+C), C$ being stream in $\mathrm{ft} . / \mathrm{sec}$., and negative for weather going. Let $E_{1} G_{1}$ apply to a given position, and $E_{2} G_{2}$ to another position a mile to leeward. The increase in wave power within that distance, that is, over a strip of water a mile long and a foot wide, will be $E_{2} G_{2}-E_{1} G_{1}$ in slack water, and $E_{2} G_{2}-$ $E_{1} G_{1}+C\left(E_{2}-E_{1}\right)$ with stream $C$. That would only be strictly correct if the wind could be so adjusted that $E_{2}$ and $G_{2}$ might retain their slack-water values. Then $C\left(E_{2}-E_{1}\right)$ would be the change which $C$ entails in the demand for power, but it may also be taken as a rough estimate of the surplus available for increasing the sea when the stream has made to the weather without change in wind, a surplus additional to any due to greater speed of wind over water. To put this in another way, $\frac{d(E C)}{d F^{\prime}}=16 H C \cdot \frac{d H}{d F}=18 C$ ft.-1b. per sq. ft. per sec. per mile, for Stevenson's highest waves with long fetches. The corresponding expression for short fetches would be $\left(18+34 F^{-\frac{1}{2}}-18 F^{-\frac{1}{4}}-10 F^{-\frac{3}{4}}\right) C$, giving $24 C, 19 C, 17 \cdot 5 C, 16 \cdot 8 C, 16 \cdot 3 C, 16 C, 15 \cdot 8 C$ for the fetches in the table.

To take an example, the value of $18 \mathrm{C}$ for a 3 -knot stream is 90 , a constant surplus for weather going, and deficiency for lee going, stream comprised in the increasing slack water figures for $d: P / d . F$ for the longer fetches in the table. Thus, as with swell, stream seems to have less proportionate effect on longer waves; and from the way in which the sea steepens when the stream turns to the weather, it looks as if the surplus is used in heightening rather than in lengthening them, and so in intensifying rather than in speeding up their energy. But this line of reasoning for the case in which a weather shore has to be taken into account has obvious defects, and it is only put forward in the hope that someone may be able to explain what really happens.

Now as to subsidence. The rate at which swell subsides owing to the viscosity of the water can scarcely be measured, but it has been calculated by Stokes, who, taking as examples waves 2 in. and $240 \mathrm{ft}$. long, has shown that it is much slower for the longer waves. Unfortunately, his formula gives the daily loss in height for the 240 -ft. waves as only $\frac{1}{4}$ per cent, and this seems much too small. In fact, a steepish swell only $100 \mathrm{ft}$. long should subside into an almost flat calm after. a couple of days, whereas by formula it would only lose a tenth of its height a week. The probability is that other effects preponderate. Thus a short sea is generally local, and always so in narrow waters. Therefore the tail of its energy will soon pass on, and leave a calm behind.
Again, waves lose height because their energy only travels half as fast as they do, and the shorter waves will lose height more quickly on this account. Compare two hypothetical swells, with 6,000 waves, $400 \mathrm{ft}$. and $100 \mathrm{ft}$. in length. They will cover 400 and 100 miles to start with. The middle waves of each will start to lose height, for the reason mentioned, when they have travelled through these distances, that is, after 15 and $7 \frac{1}{2}$ hours, as the case may be.

The modulus of viscosity is based on frictional action between layers shearing one over the other. On the other hand, water movement under wave action involves two-dimensional distortion, what were elementary cubes in calm being distorted, approximately, from upright to horizontal oblongs, cubical form being passed midway. If the work done against viscosity were proportional to the linear distortion of the cubes, the loss in wave height per second would be absolute, and not a percentage one, and proportional to $L-\frac{1}{2}$, while the distance through which the waves would have to travel before they completely flatten down would be proportional to $L H$. That seems more in accordance with ordinary experience.

Perhaps an actual example will be more convincing. The period of the surf on the Guinea Coast, 10 12 sec., is about double the ordinary period of waves in the Straits of Dover. The surf probably originates in energy that has travelled from the Southern Ocean, a journey of at least a week, while hours rather than days would be the measure of the time of calming in the Straits.

But to return to the original question of length and height in relation to wind and fetch. Determination of the empirical laws should go some way towards solving the problems that surround windforced waves. Measurements taken at lee shores with various but preferably small exposures, during steady winds of various strengths, might give some clues, and they could easily be made where the conditions are suitable. In any event, waves affect so many things, ships-breakwaters, erosion and littoral drift-that further knowledge as to their behaviour can scarcely fail to pay.

1 Vaughan Cornish, "Waves of the Sea", 87.

${ }^{2}$ Jeffreys, H., Proc. Roy. Soc., A, 10\%, 189.

stevenson, Thomas, "The Design and Construction of Harbours"" 2nd ed., 22-26.

"Phil. Mag., (6) 23, 1055 (1913).

"Gaillard, "Wave Action", 32, 76.

- See also Vaughan Cornish, "Waves of the Sea", 121.

7 Stokes, "Math. and Phys. Papers", 3, 42 (with footnote).

\section{NEW SEISMOGRAPH STATION AT LOGAN, UTAH}

1

HE installation of a seismograph at Utah State Agricultural College was made possible through a gift from the estate of the late Thomas E. Oldham, an English-born resident of Logan, who died in 1938 ("The Oldham Seismograph station at Utah State Agricultural College, Logan, Utah", by J. Stewart Williams, Bull. Seis. Soc. Amer., 32, No. 1, January, 1942). The name is a very happy one in view of the history of seismology, though the late Thomas E. Oldham of Utah bears no known relationship to Thomas Oldham of the Geological Survey of India (1816-1878), and R. D. Oldham his son (1858-1936), who first recognized the longitudinal and transverse 
character of the two types of preliminary waves of an earthquake.

The seismograph room is in the basement of the main college building, the approximate geographical location being latitude $41^{\circ} 45^{\prime} \mathrm{N}$., longitude $111^{\circ}$ $47^{\prime} \mathrm{W}$. The station is equipped with two horizontal component Wood-Anderson seismographs bought with the gift, and an accelerograph installed by the United States Coast and Geodetic Survey. The seismometers are mounted on concrete blocks $28 \mathrm{~cm}$. high, keyed into the surface of a pier, resting in wellcemented gravels of the Bonneville delta, and stand. ing at a height of $4,772 \cdot 3 \mathrm{ft}$. above sea-level. , Installation of the accelerograph was completed in July 1939 and the Wood-Anderson instruments began operation on January 26, 1940. Since October 1, 1940, all seismograms have been checked by the United States Coast and Geodetic Survey, and the results will be published in the monthly seismographic report.

The north-south seismometer has a static magnification of $716 \cdot 8$, the east-west seismometer one of 697.9. The period for both is maintained at $6 \cdot 0$ seconds, the damping ratio at $20: 1$. The recording drum has so far been run at $15 \mathrm{~mm} . / \mathrm{m}$. The seismo. meters are in protective coverings which are also provided with water cans in an attempt to eliminate temperature variations near the instruments. The accelerograph, lent and maintained by the United States Coast and Geodetic Survey, is a No. $M-45$, with a 12-in. recorder, and has three components.

The site appears to be a particularly happy one, especially for the accelerographs, since Utah appears to be the most seismically active of the Rocky Mountain States. This latter may be related to the zone of faulting that marks the eastern margin of the Great Basin. One centre of activity has been in Washington and Iron Counties, adjacent to the Hurricane fault, and another centre lies in Sevier County between the Tushar and Sevier faults. Nearly one third of the earthquakes of Utah have occurred close to the Wasatch fault.

\section{FORTHCOMING EVENTS}

(Meetings marked with an asterisk are open to the public)

Wednesday, May 27

Physical, Society (Colodr Grodp) (at the Royal Photographic Society, 16 Princes Gate, London, S.W.7), at 2.30 p.m.-Discussion on "The Relative Merits of Spectrophotometry and Colorimetry" (to be opened by Miss Dorothy L. Tilleard).

INSTITUTh of ChEMTSTRY (LONDON AND SOUTh EASTERN CoUNTIES SkCTION) (at 30 Russell Square, London, W.C.1), at 6 p.m.-Dr. H. Baines: "Recent Advances in Photographic Theory".

\section{Thursday, May 28} BRITISH PSYchotoatcal SOcIETX (INDUSTRIAt, SEOTION) (at the
National Institute of Industrial Psychology, Aldwych House, Aldwych, London, W.C.2), at 1.20 p.m.- Miss May Smith: "Fatigue, a Revision of Past and Survey of Present Problems".

\section{Friday, May 29}

Royal Institution of Great Britain (at 21 Albemarle Street, London, W.1), at 5.15 p.m.-Mr. Seton Gordon: "Wild Life in the

BRITISH INSTITUTION OF RADIO ENGINFERS (LONDON SECTION) (at the Federation of British Industries, 21 Tothill Street, London, S.W.1) at 7 p.m.-Mr. O. S. Puckle: "Time Bases"."

Instirute of Physics (MANChester AND District BRANCH) (in the Physics Department, University of Manchester), at 7 p.m.-Dr.

\section{Saturday, May 30}

NUTRITION Soctery (at the London School of Hygiene and Tropical Medicine, Keppel Street, London, W.C.1), at .11 a.m.-Conference on "Problems of Collective Feeding in War-time".

\section{APPOINTMENTS VACANT}

APPLICATIONS are invited for the following appointments on or

METALLURGIST for research work in connexion with problems attending colliery wire ropes and other coal-mining appliances-The Chief Executive Officer, Safety in Mines Research Laboratories, Portobello Street, Sheffield 1 (May 29).

SPEECH THERAPIST (WOMAN) - The Director of Education, Education Offices, Woodlands Road, Middlesbrough (May 30 ).

Tracher of Mathematics and a Tracher of PHYSics-The Principal, South-West Essex Technical College and School of Art, Forest Road, Walthamstow, London, E.17 (May 30).

Lecturer IN ScIende-The Principal, Domestic Science Training College, Knighton Fields, Leicester (May 31).

Electrical Engineer and MaNager-The Town Clerk, Town Hall, St. Helens, Lancs. (endorsed 'Appointment of Electrical Engineer and Manager') (June 1.)

SENTOR LECTURER (MAN OR WOMAN) in the SOIENCE DEPARTMENT of the City of Leeds Training College, with special qualiflcations in BIOLOGY - The Director of Education, Education Offices, Leeds 1 June 1).

Chinf Laboratorx Steward-The Principal, Technical College, Doncaster.

Senior Woman Lecturer in Biology-The Principal, Southlands Training College (London), at Highbury, Atlantic Road, Westonsuper-Mare.

Mistress to TAKE ChaRge OF THE Generat, SCIENCE WORKThe Headmistress, Day Technical School for Girls, Fort Pitt, Chatham.

\section{REPORTS and other PUBLICATIONS} (not included in the monthly Books Supplement)

\section{Great Britain and Ireland}

South-West Essex Technical College and School of Art. Annual Report, Session 1940-41. Pp. $23+4$ plates. (London : South-West Proceedings of the Royal Irish Academy. Vol 47, Section [45 6: Inherent Relations between Random Variables, Section A, No. Geary. Pp. 63-76. 18. Vol. 47, Section B Variables. By Dr. R. C. Geary. Pp. $63-76$. 18. Vol. 47, Section B, No. $13:$ R. Liffey Survey, Water. By Winifred E. Frost. Pp. 293-369+plate 6. 5s. Vol. 47, Section B, No. 14: The Exploration of some Caves near Castletownroche, Co. Cork (Studies in Irish Quaternary Deposits, No. 4). By A. M. Gwynn, G. F. Mitchell and A. W. Stelfox. Pp. 371-390+plate 7. 1s. 6d. Vol, 48, Section B, No. 1: The Distribution of Phytoplankton in some North-West Irish Loughs. By W. H. Pearsall and Edna M. Lind. Pp. 24. 18. (Dublin : Hodges, Figgis and Co., Ltd.;
London: Williams and Norgate, Ltd.)

\section{Other Countries}

Smithsonian Institution : United States National Museum. Bulletin 161: The Foraminifera of the Tropical Pacific Collections of the Albatross, 1899-1900. Part 3: Heterohelicidae and Buliminidae. By Joseph Augustine Cushman. Pp. v $+67+15$ plates. (Washington,
D.C.: Government Printing Office.) 20 cents.
[274 Ministry of Finance: Survey of Egypt. Survey Paper No. 45 Map Projections in Practice. By J. H. Cole. Pp. iii +43. (Giza : Survey of Egypt.)

U.S. Department of Agriculture. Circular No. 632: Rice-Field Insects. By W. A. Douglas and $T$. W. Ingram. Pp. 32 , (Washington, D.C.: Government Printing Office.) 10 cents. P. 32 . (Washington, Indian Central Cotton Committee: Technological Laboratory. Technological Bulletin, Series A, No. 53: Technological Reports on Trade Varieties of Indian Cottons, 1941. By Dr. Nazir Ahmad. Pp. vii +103 . 1.8 rupees. Technological Bulletin, Series A, No. 54 Technological Reports on Standard Indian Cottons, 1941. By Dr. Nazir Ahmad. Pp. ii +115. 1.8 rupees. (Bombay: Indian Centra]
Cotton Committee.)

Bureau of Education, India. Education in India in 1937-38. Pp. vii +109 . 2.8 rupees ; 48 . Education in India in 1938-39. Pp. vii + Indian Forest Records (New Series). Botany, Vol. 3, No. 2 : Some Additions to the "Botany of Bihar and Orissa". By H. F. Mooney. Pp. v+63-120. 2 rupees; 38. Botany, Vol. 3, No. 3: Five New Indian and Burmese Flowering Plants-Ceropegia bori $\mathrm{M}$. B. Raizada, Bauhinia lyrata M. B. Raizada, Nextunia robertsonii M. B. Raizada, Capparis chamoensis M. B. Raizada, and Phlogacanthus pochinii M. B. Raizada. By M. B. Raizada. Pp. iii $+121-128+5$ plates. 14 annas ; 1s. 3d. Botany, Vol. 3, No. 6 : The Reliet Vegetation of the Shillong Plateau, Assam. By Dr. N. L. Bor. Pp. v+152-195. 2.2 rupees Regeneration Details of the Dry Fuel Forests of Madras. By A. L. Griffith. Pp. iv +161-224+4 plates. 2.8 rupees; 48 . (Delhi : Manager of Publications.

Forest Research Institute, Dehra Dun. Leaflet No. 6: Note on some Experiments on Cork Substitutes. By Dr. D. Narayanamurti. Pp. ii $+4+1$ plate. Leaflet No. $7:$ A New Type of Veneer Drying
Rack. By M. A. Rehman and Sultan Mohammad. Pp. ii $+4+2$ plates. (Dehra Dun: Forest Research Institute, )

Herbertia. Vol. 8: Daylily edition. Edited by Hamilton P. Traub. Pp. 186 (27 plates). (Orlando, Fla.: American Amaryllis Society.) 3.25 dollars. 